\title{
SYNTHESIS OF A CARBON-11 LABELED NONSTEROIDAL ANTIANDROGEN AS A POTENTIAL RADIOLIGAND FOR PET IMAGING OF PROSTATE CANCER
}

\author{
M. E. Van Dort, D. M. Jewett, Y-W Jung, P. S. Sherman, \\ K. K. Kuszpit \\ Division of Nuclear Medicine \\ Department of Radiology \\ University of Michigan Medical School \\ Ann Arbor, MI 48109-0552
}

Key Words: androgen receptor, antiandrogen, carbon-11, nonsteroidal, PET, prostate cancer

The hormone dependency of prostate cancer is well established and androgen receptor (AR) expression is frequently observed in primary prostate tumors and metastases (1). As a consequence, the development of radioligands that target the $\mathrm{AR}$ for prostate tumor imaging is an active area of research (2). The majority of these studies to date have focused on steroid-based ligands, including the naturally occurring androgens (testosterone, dihydrotestosterone) and synthetic steroids (mibolerone, metribolone) $(3,4)$.

The recent emergence of AR-selective, high-affinity, nonsteroidal antiandrogens such as RU 59063, (Table 1), offers a useful alternative approach towards AR radioligand development (5). Our goal in this study was to develop a suitable carbon-11 labeled nonsteroidal AR radioligand for PET imaging of prostate cancer. We recently showed that replacement of the trifluoromethyl group of RU 59063 with iodine (DTIB, Table 1) leads to a 3-fold enhancement in AR binding affinity (6). This observation led us to synthesize the $N$-methylated hydantoin and thiohydantoin derivatives $(1 \mathbf{a}, 1 \mathbf{b})$, which were subsequently shown to retain high affinity towards AR (Table 1). Since the synthesis of $\left[{ }^{11} \mathrm{C}\right] \underline{1 \mathrm{~b}}$ by direct $N-\left[{ }^{11} \mathrm{C}\right]$ methylation of its normethyl precursor is not feasible (due to preferential methylation on sulfur), the $N$-methyl derivative 1a was selected for carbon-11 labeling. We report here the radiosynthesis of $\left[{ }^{11} \mathrm{C}\right] \underline{\mathbf{1 a}}$ for evaluation as a $\mathrm{AR}$ radioligand for $\mathrm{PET}$. 
Table 1. Inhibition Constants (Ki) for Ligands at the Rat $A R$<smiles>[X]c1cc(N2C(=O)C(C)(C)N(P)C2=[V])ccc1C#N</smiles>

\begin{tabular}{|c|c|c|c|c|}
\hline Compd & $\mathbf{X}$ & $\mathbf{Y}$ & $\mathbf{R}$ & $\mathbf{K i} \pm$ SEM (nM) \\
\hline RU 59063 & $\mathrm{CF}_{3}$ & $\mathrm{~S}$ & $\left(\mathrm{CH}_{2}\right)_{4} \mathrm{OH}$ & $2.23 \pm 0.50$ \\
\hline DTIB & $\mathrm{I}$ & $\mathrm{S}$ & $\left(\mathrm{CH}_{2}\right)_{4} \mathrm{OH}$ & $0.71 \pm 0.22$ \\
\hline$\underline{\mathbf{1 a}}$ & $\mathrm{I}$ & $\mathrm{O}$ & $\mathrm{CH}_{3}$ & $11 \pm 5$ \\
\hline$\underline{\mathbf{1 b}}$ & $\mathrm{I}$ & $\mathrm{S}$ & $\mathrm{CH}_{3}$ & $2.5 \pm 0.7$ \\
\hline
\end{tabular}

Figure $1^{\text {a }}$<smiles>N#Cc1ccc(N)cc1I</smiles>
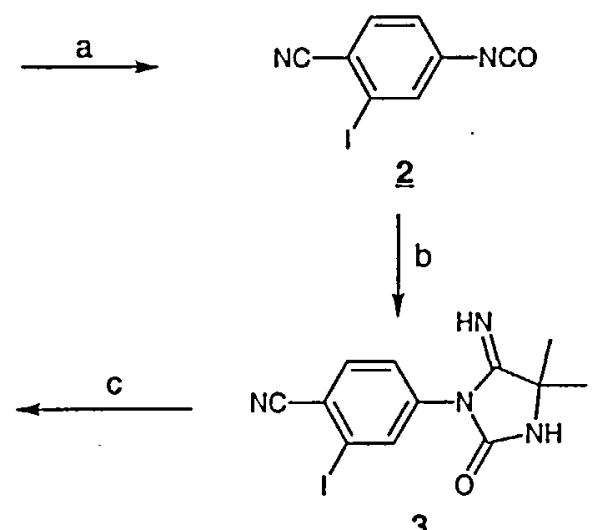

4

$e\left(\begin{array}{l}\mathrm{R}=\mathrm{H} ; 4 \\ \mathrm{R}=\mathrm{CH}_{3} ; \underline{1 \mathrm{a}} \\ \mathrm{R}={ }^{11} \mathrm{CH}_{3} ;{ }^{\left.1{ }^{11} \mathrm{C}\right] 1 \mathrm{a}}\end{array}\right.$

${ }^{a}$ Reagents and conditions: (a) $\mathrm{COCl}_{2}$, toluene, $\mathrm{r}$; (b) 2-amino-2-cyanopropane, $\mathrm{El}_{3} \mathrm{~N}$,

1.2-DCE, reflux; (c) $2 \mathrm{~N} \mathrm{HCl}, \mathrm{CH}_{3} \mathrm{OH}$, reflux; (d) 1. $\mathrm{NaH}$ 2. $\mathrm{CH}_{3}$; (e) 1. KF/Alumina $2 . ~ " \mathrm{CH}_{3} \mathrm{l}$. 
A four step synthetic route starting from 4-cyano-3-iodoaniline provided 1a in $37 \%$ overall yield (Figure 1). Radiosynthesis of $\left[{ }^{11} \mathrm{C}\right] \underline{1}$ a with $\left[{ }^{11} \mathrm{C}\right] \mathrm{CH}_{3} \mathrm{I}$ was conducted in a microcolumn by a captive solvent method following adsorption of the normethyl precursor of 1a on a solid phase mixture of $20 \% \mathrm{KF}$ and $2 \%$ water in alumina. The labeled product was eluted with anhydrous ether through a column of basic alumina, concentrated, and dissolved in physiological saline:EtOH (95:5) for animal studies. The radiochemical yield and specific activity of the product were $45 \%(\mathrm{EOB})$ and $>1300 \mathrm{Ci} / \mathrm{mmole}(\mathrm{EOS})$, respectively.

In conclusion, a reliable and efficient synthesis of a carbon-11 labeled nonsteroidal androgen receptor ligand is reported. Biological studies are underway to determine the applicability of [ $\left.{ }^{11} \mathrm{C}\right] \underline{12}$ as a PET radioligand for AR imaging.

\section{References}

1. Hobisch A., Culig Z., Radmayr C., Bartsch G., Klocker H., Hittmair A. -The Prostate 28: 129 (1996).

2. Katzenellenbogen J.A.- J. Nucl. Med. 36(Suppl): 8S (1995).

3. Bonasera T.A., O'Neil J.P., Xu M., Dobkin J.A., Cutler P.D., Lich L.L., Choe Y.S., Katzenellenbogen J.A., Welch M.J.- J. Nucl. Med. 37: 1009 (1996).

4. Liu A.J., Katzenellenbogen J.A., Van Brocklin H.F., Mathias C.J., Welch M.J.-J. Nucl. Med. 32: 81 (1991).

5. Teutsch G., Goubet F., Battmann T., Bonfils A., Bouchoux F., Cerede E., Gofflo D., Gaillard-Kelly M., Philibert D.- J. Steroid Biochem. Molec. Biol. 48: 111 (1994).

6. Van Dort M.E., Robins D.M., Wayburn B.- J. Med. Chem. 43: 3344 (2000).

Acknowledgement

This work was supported by grants from the National Institutes of Health

(CA 77287) and the SPORE in Prostate Cancer (P50 CA 69568). 